\title{
Yield, water use and water use efficiency of pigeonpea [Cajanus cajan ( $L$. Millsp.] under drip fertigation system
}

\section{Vimalendran* and K. R. Latha}

Department of Agronomy, Tamil Nadu Agricultural University, Coimbatore - 641003 (Tamil Nadu), INDIA *Corresponding author. E-mail: vimal.tnau@gmail.com

Received: May 04, 2014 Revised received: August 08, 2014 .; Accepted: October 07, 2014

\begin{abstract}
Field experiments were carried out during two seasons (August-February) of 2011-12 and 2012-13 at Millet Breeding Station, Tamil Nadu Agricultural University, Coimbatore, to study the effect of drip fertigation on productivity, water use and water use efficiency of pigeonpea (Cajanus cajan) cv. LRG 41. The treatments included three irrigation regimes (50\%, $75 \%, 100 \%$ computed water requirement of crop) and surface irrigation along with three fertilizer levels with water soluble fertilizer (WSF) and conventional fertilizers (CF). The treatments were laid out in Randomized Block Design with three replications. The results revealed that drip irrigation at $100 \%$ WRc with fertigation at $125 \%$ RDF through WSF registered significantly highest grain yield of 2812 and $2586 \mathrm{~kg} \mathrm{ha}^{-1}$ during 2011-12 and 2012-13, respectively. Surface irrigation with conventional method of fertilizer application recorded lower water use efficiency of 3.70 and $3.38 \mathrm{~kg} \mathrm{ha}^{-1} \mathrm{~mm}^{-1}$ whereas it was reverse with drip irrigation of $100 \%$ WRc + $125 \%$ RDF through WSF with a WUE of $6.97 \mathrm{~kg} \mathrm{ha}^{-1} \mathrm{~mm}^{-1}$ during 2011-12 and during second season (2012-13), the highest WUE of $6.72 \mathrm{~kg} \mathrm{ha}^{-1} \mathrm{~mm}^{-1}$ was recorded in drip irrigation at $50 \%$ WRc along with fertigation at $125 \%$ RDF through WSF. The increase in grain yield with drip irrigation at $100 \%$ WRc + fertigation with $125 \%$ RDF through WSF was mainly attributed by greater and consistent availability of soil moisture and nutrients which resulted in better crop growth, yield components and ultimately reflected on water use efficiency and yield of pigeonpea Cajanus cajan.
\end{abstract}

Keywords: Drip fertigation, Water use, Water use efficiency, Yield

\section{INTRODUCTION}

Pigeonpea [Cajanus cajan (L.) Millsp.] has been considered as second most important crop after chickpea (Cicer arietinum). India has virtual monopoly in pigeonpea production accounting to $90 \%$ of world's total production. In India, pigeonpea is grown in an area of 4.37 m.ha, with a production of $2.65 \mathrm{~m} . \mathrm{t}$ and the average productivity is $655 \mathrm{~kg} \mathrm{ha}^{-1}$. More than 85 $\%$ area of pigeonpea is under rainfed. The demand for pulses is increasing due to increasing population. Indian Council of Medical Research recommends about $60 \mathrm{~g} / \mathrm{day} /$ person but the average intake is only 31 g/day (NNMB, 2012). To meet the demand, pigeonpea productivity has to be increased. Drip fertigation is the precise application of irrigation water and fertilizer in the root zone. Effective management of irrigation water is an important issue in crop production, since irrigation is a precondition for crop growth, development and production per mm of water and productivity per unit area. Drip irrigation is a technique in which water flows through a filter into special drip pipes, with emitters located at different spacing. Water is distributed through the emitters directly into the soil near the plants through a special slow-release device. If the drip irrigation system is properly designed, installed, and managed, it may help to achieve water conservation by reducing evaporation and deep drainage. Irrigation scheduling can be managed precisely to meet crop demands, holding the promise of increased yield and quality. Adoption of drip irrigation might help in increasing area under irrigation, productivity of crops and increase the water use efficiency (Tarawalie et al., 2012). Drip irrigation is the direct application of water in the root zone with enhanced WUE. To meet out the requirement the only way is to increase the production and productivity for that drip irrigation is the best option. Hence, the present study was initiated to study the influence of drip fertigation on yield, water use and water use efficiency of pigeonpea [Cajanus cajan (L.) Millsp.] under drip fertigation in Western Agroclimatic Zones of Tamil Nadu.

\section{MATERIALS AND METHODS}

Field location: Field experiments were conducted during August - February of 2011-12 and 2012-13 at Millet Breeding Station, Agricultural College and Research Institute, Tamil Nadu Agricultural University, Coimbatore to study the effect of drip irrigation and fertigation levels on yield, water use and 
water use efficiency of pigeonpea. The experimental location is geographically situated in the Western Agro -climatic Zone of Tamil Nadu at $11^{\circ}$ North latitude and 77. East longitude at an altitude of $426.7 \mathrm{~m}$ above MSL. The long term average annual precipitation of Coimbatore (mean of 30 years) is $720.8 \mathrm{~mm}$ distributed over 47 rainy days. The two monsoon rainy seasons viz., South West Monsoon and North East Monsoon contribute a rainfall of 26.2 and $51.6 \%$ respectively and the peak month of rainfall is October (186 mm). During first season (2011-12), the maximum temperature ranged from 27.3 to $33.6^{\circ} \mathrm{C}$ with a mean of $30.4^{\circ} \mathrm{C}$ and minimum temperature ranged from 15.2 to $23.1^{\circ} \mathrm{C}$ with a mean of $20.7^{\circ} \mathrm{C}$. The total rainfall received during the cropping period was $630.1 \mathrm{~mm}$. The pan evaporation ranged from 1.8 to $6.1 \mathrm{~mm}$ with a mean of $4.1 \mathrm{~mm}$. The solar radiation ranged from 224.0 to $462.6 \mathrm{cal} \mathrm{cm}^{-2}$ day $^{-1}$ with a mean of $364.5 \mathrm{cal} \mathrm{cm}^{-2} \mathrm{day}^{-1}$ (Fig. 1).

During 2012-13, the second crop season, the maximum temperature ranged from 28.0 to $33.3{ }^{\circ} \mathrm{C}$ with a mean of $31.1^{\circ} \mathrm{C}$ and minimum temperature ranged from 17.8 to $23.3^{\circ} \mathrm{C}$ with mean of $21.0^{\circ} \mathrm{C}$. The total rainfall received during the cropping period was $217.2 \mathrm{~mm}$. The pan evaporation ranged from 2.8 to $7.2 \mathrm{~mm}$ with a mean of $5.0 \mathrm{~mm}$ and the solar radiation ranged from 254.1 to 471.6 cal cm day $^{-1}$ with a mean of $372.42 \mathrm{cal} \mathrm{cm}^{-2}$ day ${ }^{-1}$ (Fig. 2). The soil of the experimental site was sandy clay loam in texture classified taxonomically as Typic Ustropept. The experimental site was texturally classified as sandy clay loam having $26.75 \%$ moisture at field capacity, $12.50 \%$ at permanent wilting point and 1.36 $\mathrm{Mg} \mathrm{m}^{-3}$ in situ bulk density. The $\mathrm{pH}$, organic carbon content and EC values were 7.55, $0.51 \%$ and $0.78 \mathrm{~d}$ $\mathrm{sm}^{-1}$ respectively. The soil was low in available nitrogen $\left(226 \mathrm{~kg} \mathrm{ha} \mathrm{ha}^{-1}\right.$, medium in available phosphorus (18 $\mathrm{kg} \mathrm{ha}^{-1}$ ) and high in available potassium (429 kg ha-1).

Treatment details: The experiments were laid out in a Randomized Block Design with fourteen treatments and three replications. The treatments included combination of water and nutrients levels. Three irrigation regimes viz., $50 \%, 75 \%, 100 \%$ computed water requirement of the crop (WRc) along with surface irrigation and three fertilizer levels (with conventional fertilizers and water soluble fertilizers) formed the treatment combinations. The treatments were: $\mathrm{T}_{1}-50 \% \mathrm{WRc}+75 \%$ recommended dose of fertilizers (RDF) through water soluble fertilizers (WSF), $\mathrm{T}_{2-} 75 \% \mathrm{WRc}+75 \% \mathrm{RDF}(\mathrm{WSF}), \mathrm{T}_{3^{-}} 100 \%$ $\mathrm{WRc}+75 \% \mathrm{RDF}(\mathrm{WSF}), \mathrm{T}_{4^{-}} 50 \% \mathrm{WRc}+100 \%$ RDF i.e., 25:50:25 NPK kg ha ${ }^{-1}$ (WSF), $\mathrm{T}_{5}-75 \% \mathrm{WRc}$ $+100 \% \mathrm{RDF}(\mathrm{WSF}), \mathrm{T}_{6^{-}} 100 \% \mathrm{WRc}+100 \% \mathrm{RDF}$ (WSF), $\mathrm{T}_{7-} 50 \% \mathrm{WRc}+125 \% \mathrm{RDF}(\mathrm{WSF}), \mathrm{T}_{8^{-}} 75 \%$ $\mathrm{WRc}+125 \% \mathrm{RDF}(\mathrm{WSF}), \mathrm{T}_{9^{-}} 100 \% \mathrm{WRc}+125 \%$ $\mathrm{RDF}(\mathrm{WSF}), \mathrm{T}_{10^{-}} 50 \% \mathrm{WRc}+100 \% \mathrm{RDF}$ through conventional fertilizers (CF), $\mathrm{T}_{11}-75 \% \mathrm{WRc}+100 \%$ $\mathrm{RDF}(\mathrm{CF}), \mathrm{T}_{12^{-}} 100 \% \mathrm{WRc}+100 \% \mathrm{RDF}(\mathrm{CF}), \mathrm{T}_{13^{-}}$
$100 \%$ WRc (Drip) + $100 \%$ RDF (conventional fertilizers as basal) and $\mathrm{T}_{14^{-}}$Surface Irrigation $+100 \%$ $\mathrm{RDF}$ through conventional fertilizers $\left(\mathrm{N}, \mathrm{P}_{2} \mathrm{O}_{5}\right.$ and $\mathrm{K}_{2} \mathrm{O}$ applied as basal).

The recommended dose of fertilizer is 25:50:25 N, $\mathrm{P}_{2} \mathrm{O}_{5}$ and $\mathrm{K}_{2} \mathrm{O}$ respectively was supplied through conventional and water soluble fertilizers. The fertigation schedules are given in the Table 1 and 2 . For this experiment the variety used LRG 41 was, obtained from Agricultural Research Station, Lam centre, Andhra Pradesh. Seeds were sown with spacing $150 \times 60 \mathrm{~cm}(150 \mathrm{~cm}$ between lateral and $60 \mathrm{~cm}$ in between the emitter). Drip irrigation was scheduled once in seven days by calculating computed water requirement of crop (WRc). Surface irrigation was given based on IW/CPE ratio of 0.6. Water use efficiency (WUE), the amount of yield was worked out by using the following formula and expressed as $\mathrm{kg} \mathrm{ha}^{-1}$ $\mathrm{mm}^{-1}$.

$$
\text { WUE } \quad=\frac{\text { Yield }\left(\mathrm{kg} \mathrm{ha}^{-1}\right)}{\text { Total water used }(\mathrm{mm})}
$$

The data collected on various aspects related to the study were subjected to statistical analysis by Analysis of Variance (ANOVA) method as suggested by Gomez and Gomez (1984). Whenever the treatment differences were found significant, Critical Difference (CD) was worked out at $5 \%$ probability level and the values were furnished. The treatment differences found non significant are denoted as 'NS'

\section{RESULTS AND DISCUSSION}

Grain yield: Grain yield per hectare was significantly influenced by drip irrigation and fertigation treatments (Table 3). Drip irrigated pigeonpea (Cajanus cajan L. Millsp.) with WSF recorded significantly higher grain yield in both the years of study compared to surface method of irrigation. Among the drip irrigation and fertigation levels, pigeonpea crop receiving drip irrigation at $100 \% \mathrm{WRc}$ with fertigation at $125 \%$ RDF through WSF registered significantly highest grain yield of 2812 and $2586 \mathrm{~kg} \mathrm{ha}^{-1}$ during 2011-12 and 2012-13, respectively with 45 to $47 \%$ increase over surface irrigation method with recommended dose of fertilizers through conventional method of fertilizer application (1908 and $1794 \mathrm{~kg} \mathrm{ha}^{-1}$ ). Better crop growth at higher nutrient levels might have influenced the yield attributes favourably. The increase in yield might be due to better proportion of air-soil-water which was maintained throughout the life period of crop in drip irrigation as compared to surface irrigation as reported by Kadam and Karthikeyan (2006).

The grain yield of pigeonpea realized under drip irrigation at $100 \% \mathrm{WRc}$ along with fertigation at 125 $\%$ RDF (WSF) was comparable with drip irrigation at $100 \%$ WRc and fertigation at $100 \%$ RDF through WSF (2643 and $2498 \mathrm{~kg} \mathrm{ha}^{-1}$ during 2011-12 and 2012-13, respectively). The yield increase under drip 
Table 1. Fertigation schedule for long duration pigeonpea cv. LRG 41 at $100 \%$ RDF through water soluble fertilizers.

\begin{tabular}{|c|c|c|c|c|c|c|c|c|c|}
\hline \multirow{2}{*}{ Stage } & \multirow{2}{*}{$\begin{array}{l}\text { Dura- } \\
\text { tion } \\
\text { (Days) }\end{array}$} & \multirow{2}{*}{$\begin{array}{l}\text { Number of } \\
\text { applications } \\
\text { (splits) }\end{array}$} & \multirow{2}{*}{ Application time } & \multicolumn{3}{|c|}{$\begin{array}{c}\text { Nutrient supplied } \\
(\%)\end{array}$} & \multicolumn{3}{|c|}{$\begin{array}{l}\text { Quantity of nutrients } \\
\text { fertilizer grade (kg) }\end{array}$} \\
\hline & & & & $\mathbf{N}$ & $\mathbf{P}_{2} \mathbf{O}_{5}$ & $\mathrm{~K}_{2} \mathrm{O}$ & Urea & МАP & SOP \\
\hline Seedling & $1-30$ & 3 & 10,17 and 24 DAS & 20 & 40 & 0 & 2.32 & 32.78 & 0 \\
\hline Vegetative & $31-90$ & 9 & $\begin{array}{l}31,38,45,52,59,66, \\
73,80 \text { and } 87 \text { DAS }\end{array}$ & 30 & 30 & 25 & 9.87 & 24.58 & 12.5 \\
\hline Flowering & $91-120$ & 4 & $\begin{array}{l}94,101,108 \text { and } 115 \\
\text { DAS }\end{array}$ & 30 & 30 & 40 & 9.87 & 24.58 & 20 \\
\hline \multirow[t]{2}{*}{$\begin{array}{l}\text { Pod } \\
\text { development }\end{array}$} & $121-140$ & 3 & 122,129 and 136 DAS & 20 & 0 & 35 & 10.85 & 0 & 17.5 \\
\hline & & & Total & 100 & 100 & 100 & 32.91 & 81.94 & 50 \\
\hline
\end{tabular}

Table 2. Fertigation schedule for long duration pigeonpea cv. LRG 41 at $100 \%$ RDF through conventional fertilizers.

\begin{tabular}{|c|c|c|c|c|c|c|c|}
\hline \multirow{2}{*}{ Stage } & \multirow{2}{*}{$\begin{array}{l}\text { Duration } \\
\text { (Days) }\end{array}$} & \multirow{2}{*}{$\begin{array}{l}\text { Number of } \\
\text { applications } \\
\text { (splits) }\end{array}$} & \multirow{2}{*}{ Application time } & \multicolumn{2}{|c|}{$\begin{array}{c}\text { Nutrient supplied } \\
(\%)\end{array}$} & \multicolumn{2}{|c|}{$\begin{array}{l}\text { Quantity of nutrients } \\
\text { fertilizer grade (kg) }\end{array}$} \\
\hline & & & & $\mathbf{N}$ & $\mathbf{K}$ & Urea & MOP \\
\hline Seedling & $1-30$ & 3 & 10,17 and 24 DAS & 20 & 0 & 10.85 & 0 \\
\hline Vegetative & $31-90$ & 9 & $\begin{array}{l}31,38,45,52,59,66,73, \\
80 \text { and } 87 \text { DAS }\end{array}$ & 30 & 25 & 16.28 & 10.38 \\
\hline Flowering & $91-120$ & 4 & $94,101,108$ and 115 DAS & 30 & 40 & 16.28 & 16.60 \\
\hline Pod development & $121-140$ & 3 & 122,129 and 136 DAS & 20 & 35 & 10.85 & 14.53 \\
\hline & & & Total & 100 & 100 & 54.30 & 41.50 \\
\hline
\end{tabular}

Table 3. Effect of drip irrigation regimes and fertigation levels on grain yield of pigeonpea.

\begin{tabular}{|c|c|c|c|c|}
\hline \multirow{2}{*}{ Treatments } & \multicolumn{2}{|c|}{ Grain yield $\left(\mathrm{kg} \mathrm{ha}^{-1}\right)$} & \multicolumn{2}{|c|}{$\%$ yield increase over SI } \\
\hline & 2011-12 & 2012-13 & 2011-12 & 2012-13 \\
\hline $\mathrm{T}_{1}-50 \%$ WRc + Drip fertigation at $75 \% \mathrm{RDF}(\mathrm{WSF})$ & 2028 & 1993 & 6.3 & 11.1 \\
\hline $\mathrm{T}_{2}-75 \%$ WRc + Drip fertigation at $75 \% \mathrm{RDF}(\mathrm{WSF})$ & 2197 & 2096 & 15.1 & 16.8 \\
\hline $\mathrm{T}_{3}-100 \% \mathrm{WRc}+$ Drip fertigation at $75 \% \mathrm{RDF}(\mathrm{WSF})$ & 2205 & 2130 & 15.6 & 18.7 \\
\hline $\mathrm{T}_{4}-50 \% \mathrm{WRc}+$ Drip fertigation at $100 \% \mathrm{RDF}(\mathrm{WSF})$ & 2231 & 2129 & 16.9 & 18.7 \\
\hline $\mathrm{T}_{5}-75 \% \mathrm{WRc}+$ Drip fertigation at $100 \% \mathrm{RDF}(\mathrm{WSF})$ & 2447 & 2283 & 28.2 & 27.3 \\
\hline $\mathrm{T}_{6}-100 \% \mathrm{WRc}+$ Drip fertigation at $100 \% \mathrm{RDF}(\mathrm{WSF})$ & 2643 & 2498 & 38.5 & 39.2 \\
\hline $\mathrm{T}_{7}-50 \% \mathrm{WRc}+$ Drip fertigation at $125 \% \mathrm{RDF}(\mathrm{WSF})$ & 2306 & 2173 & 20.9 & 21.1 \\
\hline $\mathrm{T}_{8}-75 \%$ WRc + Drip fertigation at $125 \%$ RDF (WSF) & 2520 & 2311 & 32.1 & 28.8 \\
\hline $\mathrm{T}_{9}-100 \% \mathrm{WRc}+$ Drip fertigation at $125 \% \mathrm{RDF}(\mathrm{WSF})$ & 2812 & 2586 & 47.4 & 44.1 \\
\hline $\mathrm{T}_{10}-50 \% \mathrm{WRc}+$ Drip fertigation at $100 \% \mathrm{RDF}\left(\mathrm{CF}^{*}\right)$ & 1920 & 1816 & 0.6 & 1.2 \\
\hline $\mathrm{T}_{11}-75 \%$ WRc + Drip fertigation at $100 \% \mathrm{RDF}\left(\mathrm{CF}^{*}\right)$ & 1983 & 1873 & 3.9 & 4.4 \\
\hline $\mathrm{T}_{12}-100 \% \mathrm{WRc}+$ Drip fertigation at $100 \% \mathrm{RDF}\left(\mathrm{CF}^{*}\right)$ & 2160 & 1978 & 13.2 & 10.3 \\
\hline $\mathrm{T}_{13}$ - Drip irrigation at $100 \% \mathrm{WRc}+100 \% \mathrm{RDF}(\mathrm{CF}-$ all basal $)$ & 2070 & 1844 & 8.5 & 2.8 \\
\hline \multirow[t]{3}{*}{$\mathrm{T}_{14}$ - Surface irrigation $+100 \%$ RDF $(\mathrm{CF}$ - all basal) } & 1908 & 1794 & - & - \\
\hline & 138.7 & 120.0 & - & - \\
\hline & 285.3 & 246.7 & - & - \\
\hline
\end{tabular}

*P as basal; $\mathrm{N}$ and $\mathrm{K}$ through drip fertigation; WRc - Computed water requirement of crop; RDF - recommended dose of fertilizers (25:50:25 NPK kg ha ${ }^{-1}$ ); CF- Conventional fertilizers: SI- Surface irrigation

irrigation at $100 \% \mathrm{WRc}$ along with fertigation at 100 $\%$ RDF (WSF) was 39 to $44 \%$ over surface irrigation with conventional method of fertilizer application. Drip irrigation at $100 \% \mathrm{WRc}$ and drip fertigation with either $100 \%$ RDF or $125 \%$ RDF through WSF registered significantly higher grain yield during both the years of study than drip irrigation at $100 \% \mathrm{WRc}$ with recommended dose of conventional fertilizer applied basally. Across drip irrigation regimes, drip fertigated pigeonpea at $100 \%$ RDF through conventional fertilizer produced comparable yields with that at $75 \%$ RDF through WSF. 
Table 3. Effect of drip irrigation regimes and fertigation levels on grain yield of pigeonpea

\begin{tabular}{|c|c|c|c|c|c|c|c|c|}
\hline \multirow[t]{2}{*}{ Treatments } & \multicolumn{2}{|c|}{$\begin{array}{c}\text { Water applied } \\
(\mathbf{m m})\end{array}$} & \multicolumn{2}{|c|}{$\begin{array}{c}\begin{array}{c}\text { Effective rainfall } \\
(\mathbf{m m})\end{array} \\
\end{array}$} & \multicolumn{2}{|c|}{$\begin{array}{c}\text { Total water used } \\
(\mathbf{m m})\end{array}$} & \multicolumn{2}{|c|}{$\begin{array}{c}\text { WUE } \\
\left(\mathrm{kg} \mathrm{ha}^{-1} \mathrm{~mm}^{-1}\right)\end{array}$} \\
\hline & 2011-12 & 2012-13 & 2011-12 & 2012-13 & 2011-12 & 2012-13 & 2011-12 & 2012-13 \\
\hline $\begin{array}{l}\mathrm{T}_{1}-50 \% \text { WRc + Drip } \\
\text { fertigation at } 75 \% \mathrm{RDF} \\
\text { (WSF) }\end{array}$ & 172.0 & 227.1 & 159.4 & 96.4 & 331.4 & 323.5 & 6.12 & 6.16 \\
\hline $\begin{array}{l}\mathrm{T}_{2}-75 \% \text { WRc + Drip } \\
\text { fertigation at } 75 \% \text { RDF } \\
\text { (WSF) }\end{array}$ & 208.0 & 290.6 & 159.4 & 96.4 & 367.4 & 387.1 & 5.98 & 5.42 \\
\hline $\begin{array}{l}\mathrm{T}_{3}-100 \% \mathrm{WRc}+\text { Drip } \\
\text { fertigation at } 75 \% \mathrm{RDF} \\
(\mathrm{WSF})\end{array}$ & 244.0 & 352.2 & 159.4 & 96.4 & 403.4 & 450.6 & 5.47 & 4.73 \\
\hline $\begin{array}{l}\mathrm{T}_{4}-50 \% \text { WRc + Drip } \\
\text { fertigation at } 100 \% \text { RDF } \\
\text { (WSF) }\end{array}$ & 172.0 & 227.1 & 159.4 & 96.4 & 331.4 & 323.5 & 6.73 & 6.58 \\
\hline $\begin{array}{l}\mathrm{T}_{5}-75 \% \text { WRc + Drip } \\
\text { fertigation at } 100 \% \mathrm{RDF} \\
\text { (WSF) }\end{array}$ & 208.0 & 290.6 & 159.4 & 96.4 & 367.4 & 387.1 & 6.66 & 5.90 \\
\hline $\begin{array}{l}\mathrm{T}_{6}-100 \% \mathrm{WRc}+\text { Drip } \\
\text { fertigation at } 100 \% \mathrm{RDF} \\
\text { (WSF) }\end{array}$ & 244.0 & 352.2 & 159.4 & 96.4 & 403.4 & 450.6 & 6.55 & 5.54 \\
\hline $\begin{array}{l}\mathrm{T}_{7}-50 \% \mathrm{WRc}+\text { Drip } \\
\text { fertigation at } 125 \% \mathrm{RDF} \\
\text { (WSF) }\end{array}$ & 172.0 & 227.1 & 159.4 & 96.4 & 331.4 & 323.5 & 6.96 & 6.72 \\
\hline $\begin{array}{l}\mathrm{T}_{8}-75 \% \text { WRc + Drip } \\
\text { fertigation at } 125 \% \mathrm{RDF} \\
\text { (WSF) }\end{array}$ & 208.0 & 290.6 & 159.4 & 96.4 & 367.4 & 387.1 & 6.86 & 5.97 \\
\hline $\begin{array}{l}\mathrm{T}_{9}-100 \% \mathrm{WRc}+\text { Drip } \\
\text { fertigation at } 125 \% \mathrm{RDF} \\
\text { (WSF) }\end{array}$ & 244.0 & 352.2 & 159.4 & 96.4 & 403.4 & 450.6 & 6.97 & 5.74 \\
\hline $\begin{array}{l}\mathrm{T}_{10}-50 \% \mathrm{WRc}+\text { Drip } \\
\text { fertigation at } 100 \% \mathrm{RDF} \\
\left(\mathrm{CF}^{*}\right)\end{array}$ & 172.0 & 227.1 & 159.4 & 96.4 & 331.4 & 323.5 & 5.79 & 5.61 \\
\hline $\begin{array}{l}\mathrm{T}_{11}-75 \% \text { WRc + Drip } \\
\text { fertigation at } 100 \% \text { RDF } \\
\left(\mathrm{CF}^{*}\right)\end{array}$ & 208.0 & 290.6 & 159.4 & 96.4 & 367.4 & 387.1 & 5.40 & 4.84 \\
\hline $\begin{array}{l}\mathrm{T}_{12}-100 \% \mathrm{WRc}+ \\
\text { Drip fertigation at } 100 \% \\
\mathrm{RDF}\left(\mathrm{CF}^{*}\right)\end{array}$ & 244.0 & 352.2 & 159.4 & 96.4 & 403.4 & 450.6 & 5.35 & 4.39 \\
\hline $\begin{array}{l}\mathrm{T}_{13} \text { - Drip irrigation at } \\
100 \% \mathrm{WRc}+100 \% \\
\text { RDF }(\mathrm{CF}-\text { all basal })\end{array}$ & 244.0 & 352.2 & 159.4 & 96.4 & 403.4 & 450.6 & 5.13 & 4.09 \\
\hline $\begin{array}{l}\mathrm{T}_{14} \text { - Surface irrigation }+100 \\
\% \text { RDF }(\mathrm{CF}-\text { all basal })\end{array}$ & 300.0 & 400.0 & 215.1 & 130.6 & 515.1 & 530.6 & 3.70 & 3.38 \\
\hline
\end{tabular}

*P as basal; $\mathrm{N}$ and $\mathrm{K}$ through drip fertigation; WRc - Computed water requirement of crop; RDF - recommended dose of fertilizers (25:50:25 NPK kg ha $\left.{ }^{-1}\right)$; CF- Conventional fertilizers: SI- Surface irrigation

Water used: Improvement in water use in agriculture is essential because of the declining irrigation sources, energy costs make irrigation more expensive to crop production. The irrigation water was applied during 2011-12 was 172, 208 and $244 \mathrm{~mm}$ at 50\%, $75 \%$ and $100 \%$ respectively (Table 2). During 2012-13, irrigation was applied at $50 \%, 75 \%$ and $100 \% \mathrm{WRc}$ was $227.1,291.6$ and $352.2 \mathrm{~mm}$, respectively. The rainfall recorded during the cropping period was 670 , $217 \mathrm{~mm}$ during first and second season respectively.

The Effective Rainfall (ER) was higher (215.1 and $130.6 \mathrm{~mm}$ ) in surface irrigation when compared to drip irrigation (159.4, $96.4 \mathrm{~mm}$ ) during 2011-12 and 201213 respectively. Total water used was higher for surface irrigation 515.1 and $530.6 \mathrm{~mm}$ during 2011-12 and 2012-13 respectively compared to drip irrigation. Irrespective of the treatments, higher soil moisture use and the seasonal consumptive water use by the crop was due to higher amount of effective rainfall during first crop season and in the next year due to lower amount of effective rainfall comparatively higher amount of water was applied through drip to increase the total water used. Increase in irrigation water though increased the water use by the crop, it did not increase the grain yield proportionately which may have reduced the water use efficiency.

Water use efficiency: The data on water use efficiency of pigeonpea under drip irrigation are 


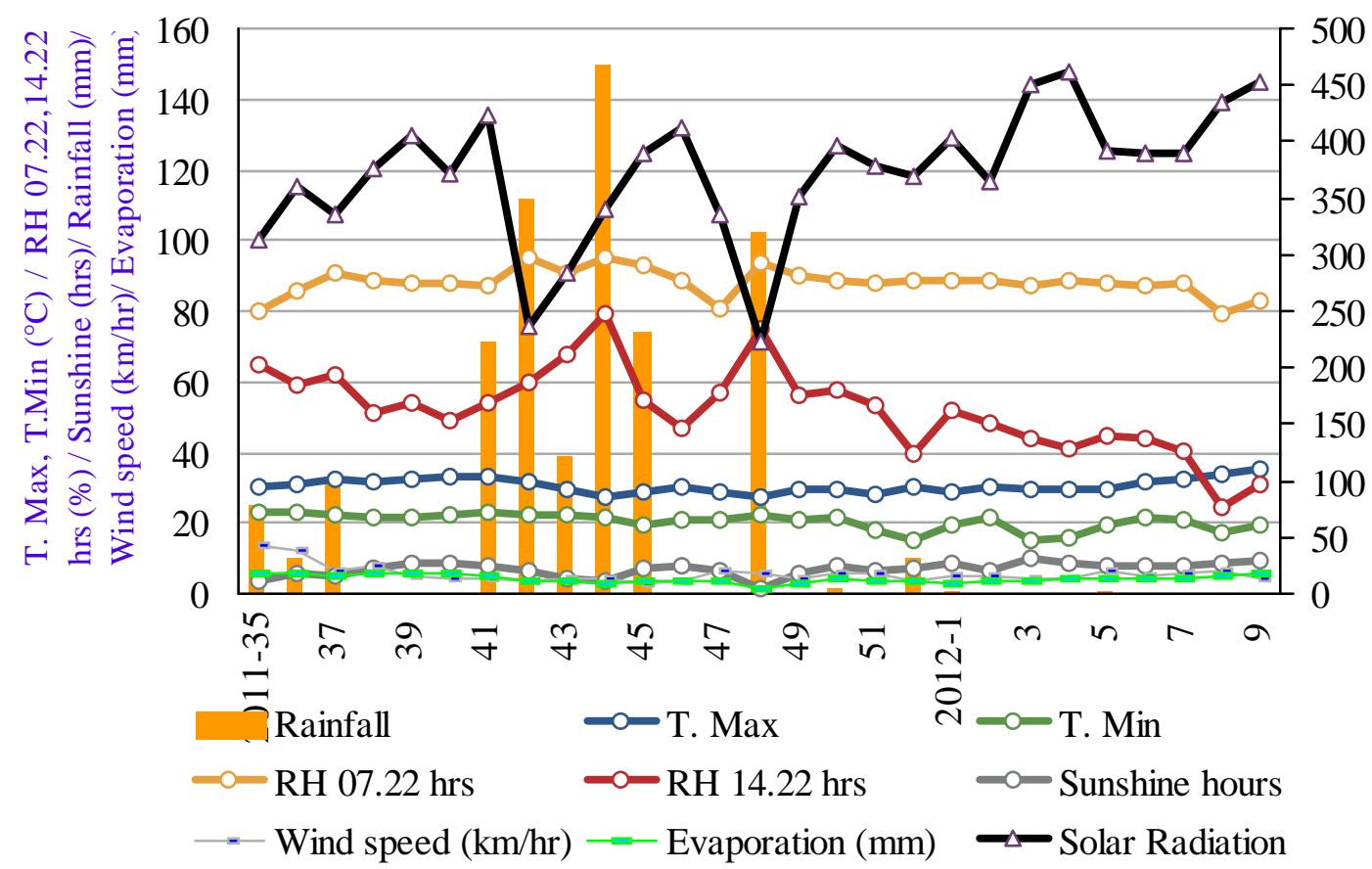

Fig 1. Weekly meteorological data prevailed during first season, 2011-12 at TNAU, Coimbatore.

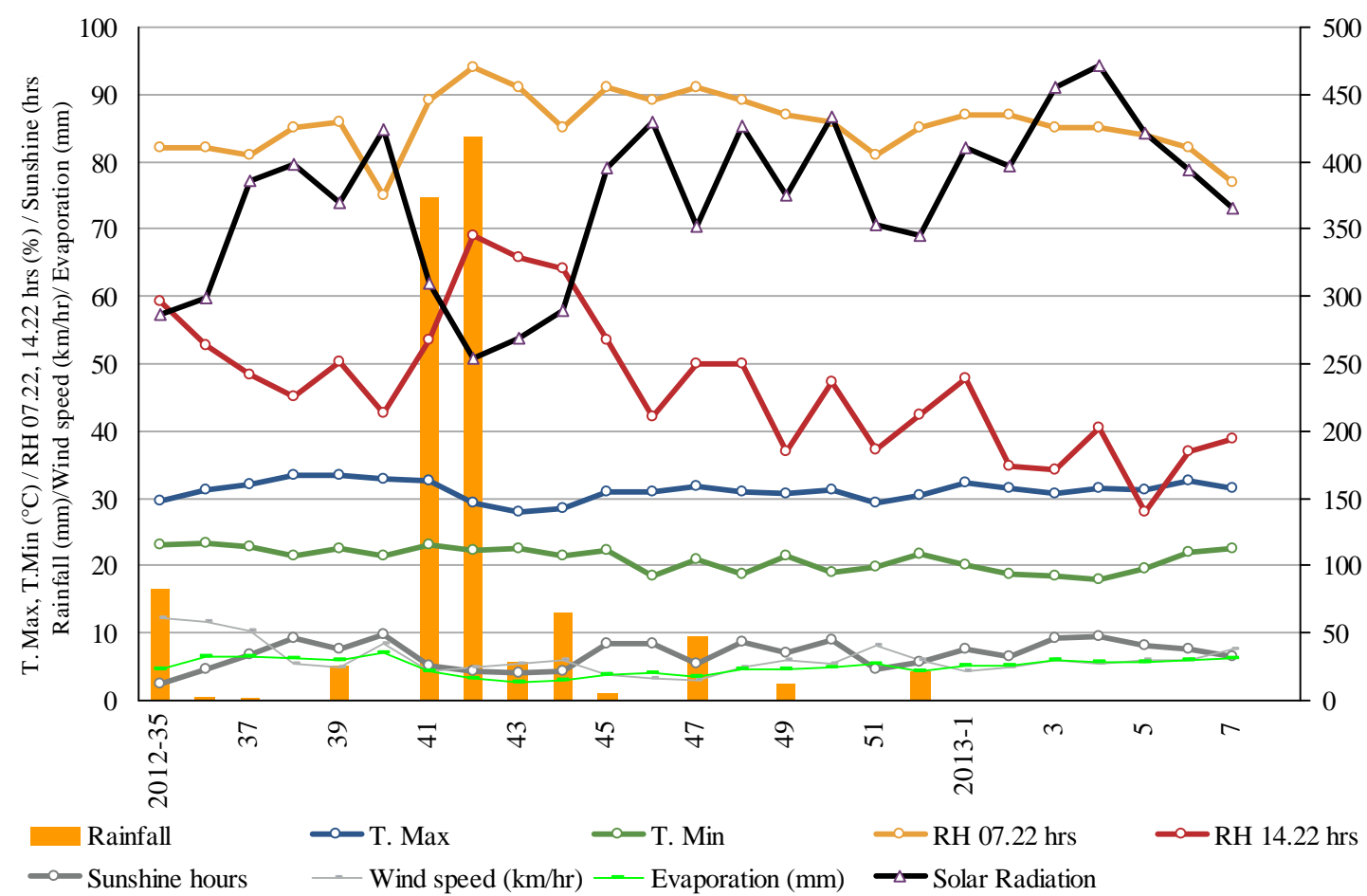

Fig 2. Weekly meteorological data prevailed during first season, 2012-13 at TNAU, Coimbatore.

furnished in Table 4. Water use efficiency is a important tool to assess the productivity of crop per unit water utilized. It was computed by the yield obtained by the crop and the total water used. Surface irrigation with conventional method of fertilizer application recorded lower water use efficiency of 3.70 and 3.38 $\mathrm{kgha}^{-1} \mathrm{~mm}^{-1}$ whereas it was reverse with drip irrigation of $100 \% \mathrm{WRc}+125 \% \mathrm{RDF}$ through WSF with a WUE of $6.97 \mathrm{~kg} \mathrm{ha}^{-1} \mathrm{~mm}^{-1}$ during 2011-12 and during second season (2012-13), the highest WUE of $6.72 \mathrm{~kg} \mathrm{ha}^{-1} \mathrm{~mm}^{-1}$ was recorded in drip irrigation at 50 $\%$ WRc along with fertigation at $125 \%$ RDF through WSF. This might be due to effective utilization of applied water.

WUE varied due to irrigation regimes as well as fertilizer levels. Similar result was obtained by Sunder 
Singh (2001) in baby corn. The increase in WUE in all drip irrigated treatments over surface irrigation was mainly due to considerable saving of irrigation water, greater increase in yield of crops and higher nutrient use efficiency. This was in concordance with Suhas Bobade et al. (2002) and Ramah (2008).

\section{Conclusion}

From this investigation it can be concluded that, drip irrigation at $100 \% \mathrm{WRc}$ along with fertigation at 125 $\%$ RDF through WSF recorded the higher yield. While under limited water situation application of $75 \% \mathrm{WRc}$ itself recoded the superior yield and water use efficiency. The results showed that increase in soil moisture regime could increase WUE up certain level, but it tended to decline. Thereafter, mainly due to considerable saving of irrigation water, there was a greater increase in yield of pigeonpea and higher nutrient use efficiency.

\section{REFERENCES}

Gomez, K. A. and A. A. Gomez. (1984). Statistical Procedures for Agricultural Research. John Wiley and Sons, New York.

Kadam, J. R. and S. Karthikeyan. (2006). Effect of soluble
NPK fertilizers on the nutrient balance, water use efficiency, fertilizer use efficiency of drip system in a Tomato. Internat. J. Plant. Sci., 1: 92-94.

NNMB (2012). Diet and nutritional status of rural population, prevalence of hypertension and diabetes among adults and infant and young child feeding practices. National nutrition monitoring bureau Technical report No.26. pp-11.

Ramah, K. (2008). Study on drip irrigation in maize (Zea mays L) based cropping system. Ph. D., Thesis, TNAU, Coimbatore.

Suhas Bobade, V., Asokaraja, N. and Arthanari, P. M. (2002). Effect of drip irrigation and nitrogen levels on yield, water use and water use efficiency of brinjal. Crop Res., 24(3): 481-486.

Sunder Singh, S. D. (2001). Effect of irrigation regimes and nitrogen levels on growth yield and quality of baby corn. Madras Agric. J., 88 (7-9): 367-370.

Tarawalie, I. F., Wengang, X., Guangcheng, S. and Chunli, H. (2012). Effect of water use efficiency on growth and yield of hot pepper under partial root-zone drip irrigation condition. International Journal of Scientific \& Engineering Research, 3 (1): 1-13. 